\title{
Chemical Study by GC-MS of the Essential Oils of Certain Mints Grown In the Region of Settat (Morocco): Mentha Piperita, Mentha Pulegium and Mentha Spicata
}

\begin{abstract}
Ayoub Ainane ${ }^{*}$, Fatima khammour ${ }^{1}$, M'hamed Elkouali $^{1}$, Mohammed Talbi ${ }^{1}$, El Hassan Abba ${ }^{2}$, Sanaa Cherroud $^{2}$, Adnane Elyaacoubi ${ }^{2}$, Khadija Oumaskour ${ }^{3}$, Nabila Boujaber ${ }^{3}$, Said Benhar $^{4}$ and Tarik Ainane ${ }^{2}$
\end{abstract}

${ }^{1}$ LCAPCM, Faculty of Sciences Ben Msik, University of Hassan II, BP 7955 Casablanca, Morocco

${ }^{2}$ Superior School of Technology - Khenifra (EST-Khenifra), University of Sultan Moulay Slimane, PB 170, Khenifra, Morocco

${ }^{3}$ Faculty of Sciences Eljadida, University of Chouaib Doukkali, Eljadida, Morocco

${ }^{4}$ Institut National de Recherche Halieutique (INRH), Casablanca, Morocco

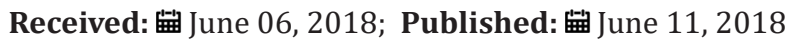

*Corresponding author: Ayoub Ainane, LCAPCM, Faculty of Sciences Ben Msik, University of Hassan II, BP 7955 Casablanca 20660, Morocco

\begin{abstract}
This work aims to evaluate the composition of the essential oils of certain mints grown in the region of Settat Morocco and to determine their chemical compositions. The essential oils obtained by hydrodistillation have an average yield of: $2.93 \%$ for Mentha pulegium, 1.23\% for Mentha piperita and 0.91\% for Mentha spicata. Analyzes of oils by GC-MS, showed the presence of several components including Menthone (42.97\%) and Menthol (27.64\%) are the major components of Mentha piperita, piperitone (31.27\%) and piperitenone (22.98\%) were obtained as the major compounds of Mentha pulegium, and so the main essential oil compounds of Mentha spicata are carvone (33.14\%) and trans-Carveol (20.06\%).
\end{abstract}

Keywords: Essential oils; Chemical composition; GC-MS; Mentha piperita; Mentha pulegium e; Mentha spicata.

\section{Introduction}

Medicinal plants are important for pharmacological research and drug development for thousands of years, man used plants found in nature, to treat and cure diseases. The use of plants in herbal medicine is very old and is currently a region of interest to the public [1]. Recently, researchers have estimated that there are about 400,000 plant species worldwide, of which about one-quarter or one-third have been used by societies for medicinal purposes $[2,3]$. Mint has a privileged place in herbal medicine; it was cultivated since ancient times for its medicinal properties. The importance of mints in the world and the interest of the Moroccan population in their use. Tradition attributes it aromatic properties (tonic, fortifying) and digestive properties (fight heaviness, bloating, etc.), used to relieve, colic, nausea, diarrhoea, and Crohn's disease [4].

\section{Material and Methods \\ Plant Material}

Samples of the aerial part (stems, leaves and flowers) of Mentha pulegium, Mentha spicata and Mentha piperita were collected in March (2018) respectively in the region of Settat (Morocco). These three species have been verified by a botanist Professor Adnane ELYAACOUBI in EST-Khénifra (University of Sultan Moulay Slimane).

\section{Extraction of the Essential Oil}

A vegetal mass which represents a proportion of about $40 \%$ is completely immersed in water (proportion of $60 \%$ ), a few grains of pumice are added, and all is then brought to a boil. The heating is maintained at a gentle temperature for 4 hours, the vapours are 
condensed in a refrigerant and the essential oil and water separate by difference in density. The HE was extracted with ethyl acetate and then dried with Na2SO4. The solvent is evaporated using a rotavapor; the oil is recovered, placed in opaque samples which are stored in the refrigerator analysis.

\section{Calculation of Yield}

The yield of essential oil (expressed as a percentage) is calculated by the ratio between the weight of the oil extracted and the weight of the plant material used [5-8]. The essential oil yield was determined with respect to the dry matter, evaluated from $100 \mathrm{~g}$ dried in an oven for $48 \mathrm{~h}$ at $60^{\circ} \mathrm{C}$. The essential oil obtained is stored at a temperature of $4^{\circ} \mathrm{C}$ in the dark.

$$
Y(\%)=\left(\frac{v}{m s} \times 100\right) \pm\left(\frac{\Delta V}{m s} \times 100\right)
$$

\section{Gas Chromatography (GC) / Mass Spectrometry (MS)}

The analysis of the essential oils was carried out by gas chromatography coupled with mass spectrometry (GC-MS). Coupling was performed on a Hewlett-Packard model 5970 (quadrupole detection system) equipped with a fused silica capillary column of $2 \mathrm{~mm} \times 0.23 \mathrm{~mm}$ DB1 type; temperature programming from $50^{\circ} \mathrm{C}$ to $200^{\circ} \mathrm{C}$, with a gradient of $5^{\circ} \mathrm{C} \mathrm{min}^{-1}$. The retention indices were determined by gas chromatography on two fused silica capillary columns $(25 \mathrm{~m} \times 0.25 \mathrm{~mm})$ of the type OV-101 and Cabowax $20 \mathrm{M}$, with temperature programming identical to that used for the coupling. (Shimatzu GC-14A equipped with a flame ionization detector and a C-R4A model integrator).

\section{Results and Discussion}

\section{Yield in Essential Oil}

The average yield of essential oil of each species was calculated according to the dry plant material obtained from the aerial parts (stems, leaves and flowers) of the plants studied. The yield of essential oil obtained is given in Table 1 . The average yields of essential oils were calculated according to the dry plant matter of the aerial part of the plant. Mentha pulegium samples were about 2.93\% higher than Mentha piperita at $1.23 \%$, and Mentha spicata at $0.91 \%$. The Mentha piperita rate is almost identical to that obtained by Adjou, E.S. et al. [5] which is (1.17\%), whereas the Mentha pulegium is lower than that obtained by Hmiri, S. et al. [6], and which is 3.30\%. for Mentha spicata the rate of return obtained by Hmiri, S. et al. [6] is almost identical which is $0.96 \%$. therefore it can be concluded that several factors could be at the origin of these variations: the age of the plants [7-8], that of the tree [9], the nature of the soil and the climate [10-11], the part of the plant subjected to extraction and the period of harvest.

Table 1: Yield in essential oils.

\begin{tabular}{|c|c|}
\hline Species & Average \\
\hline Mentha piperita & $1,23 \%$ \\
\hline
\end{tabular}

\begin{tabular}{|c|c|}
\hline Mentha pulegium & $2.93 \%$ \\
\hline Mentha spicata & $0.91 \%$ \\
\hline
\end{tabular}

\section{Chemical Composition Analysis by GC-MS}

The gas chromatographic analysis results coupled with the mass spectrometry of the essential oils of the studied plants are represented in (Tables 2). Chromatographic analyzes of essential oils made it possible to identify 26 compounds which represent approximately (99.53\%) for Mentha piperita, for Mentha pulegium 29 compounds which represent approximately (99.84\%) and for Mentha spicata 30 compounds (99.93\%) (Table 2). The analysis of the results given in Table 2 showed all of the following results: Menthone, Menthol was obtained as the majority compounds, with a percentage of (70.61\%) in the essential oil of Mentha piperita. Mentha pulegium essential is characterized by the presence of piperitone and piperitenone as major chemical constituents with a percentage of (54.25\%). and as well as the main essential oil compounds of Mentha spicata are: carvone and trans-Carveol with a percentage of (53.20\%). Analyzes carried out in Serbia on the essential oil of Mentha piperita by Sokovic MD [12], showed the presence of the following main component: menthol (37.4\%), menthyl acetate $(17.4 \%)$ and menthone $(12.7 \%)$. thus in Italy the results of Ashok, K., S [13] presented the main following compounds: menthanol $(36,24 \%)$ and menthone $(32,42 \%)$.

Table 2: Chemical composition of the essential oils of Mentha piperita, Mentha pulegium and Mentha spicata.

\begin{tabular}{|c|c|c|c|}
\hline Identification & Mentha piperita & $\begin{array}{l}\text { Mentha pule- } \\
\text { gium }\end{array}$ & $\begin{array}{l}\text { Mentha spi- } \\
\text { cata }\end{array}$ \\
\hline Sabinene & 1.24 & 0.67 & 0.13 \\
\hline$\gamma$-Terpinène & 0.25 & 0.56 & 0.98 \\
\hline Oct-1-en-3-ol & - & - & 0.25 \\
\hline Tumerone & 4.01 & - & - \\
\hline Curlone & 1.99 & 0.98 & - \\
\hline piperitenone & - & 22.98 & - \\
\hline piperitone & - & 31.27 & - \\
\hline Menthone & 42.97 & 6.58 & 2.19 \\
\hline Menthol & 27.64 & 4.31 & 1.42 \\
\hline 1,8-Cineole & 2.85 & 1.31 & 3.99 \\
\hline isomenthone & - & 0.95 & - \\
\hline neomenthol & - & 3.54 & - \\
\hline Isomenthone & 2.48 & - & 3.33 \\
\hline Limonene & 1.22 & 1.89 & 2.16 \\
\hline$\alpha$-terpineol & - & 5.07 & - \\
\hline pulegone & - & 5.80 & - \\
\hline$\alpha$-Pinene & 1.57 & - & 1.06 \\
\hline$\beta$-Pinene & 0.99 & - & 0.45 \\
\hline Germacrene-D & 1.75 & - & 3.14 \\
\hline Camphene & 0.58 & 0.02 & - \\
\hline
\end{tabular}




\begin{tabular}{|c|c|c|c|}
\hline terpinolene & - & 0.44 & - \\
\hline$\alpha$-Terpinene & - & 0.56 & - \\
\hline Nonanal & - & - & 0.24 \\
\hline Cadinene & 0.45 & 0.02 & 0.10 \\
\hline$\alpha$-Cadinol & - & - & 0.47 \\
\hline$\tau$-Cadinol & - & - & 0.56 \\
\hline $\begin{array}{l}\beta \text {-caryophyl- } \\
\text { lene }\end{array}$ & 0.02 & 0.45 & 4.41 \\
\hline$\beta$-Bourbonene & - & - & 2.14 \\
\hline$\beta$-Linalool & 0.06 & 0.33 & 0.45 \\
\hline Linalool & - & - & 0.33 \\
\hline Camphre & - & - & 1.41 \\
\hline $\begin{array}{c}\text { piperitone } \\
\text { oxide }\end{array}$ & - & 5.11 & - \\
\hline Borneol & 0.06 & - & - \\
\hline Terpinène-4-ol & 0.05 & 0.10 & 0.74 \\
\hline piperitenone & 0.03 & - & - \\
\hline Menthofuran & 0.66 & 3.46 & - \\
\hline carvone & - & 1.13 & 33.14 \\
\hline Carvone oxide & - & - & 9.72 \\
\hline b-myrcene & 1.22 & 0.04 & 0.02 \\
\hline b-Phellandrene & 1.52 & - & - \\
\hline trans-Carveol & 1.3 & 0.67 & 20.06 \\
\hline Cis-carveol & 3.35 & 1.33 & 5.30 \\
\hline Cubenol & 0.21 & - & - \\
\hline s-cadinol & 1.06 & 0.16 & - \\
\hline$\alpha$-myrcene & - & 0.02 & 1.29 \\
\hline trans-ocimène & - & 0.09 & 0.05 \\
\hline Ocimene- $\beta-Z$ & - & - & 0.31 \\
\hline Ocimene- $\beta$-E & - & - & 0.09 \\
\hline Total & 99.53 & 99.84 & 99.93 \\
\hline
\end{tabular}

Another study in Iran by Behnam, S. M [14] presented the following results: menthon (44.1\%), menthol (29.5\%), menthylacetate $(3.8 \%)$ which are the main compounds of essential oil Mentha piperita. The study conducted in Morocco by Derwich, E [15] on the aerial parts of Mentha piperita showed the predominant major compounds of the following species: Menthone (29.01\%), followed by menthol (5.58\%), menthyl acetate (3.34\%), menthofuran (3.01\%), 1,8-cineole (2.40\%), isomenthone $(2.12 \%)$, limonene $(2,10 \%), \alpha$-pinene $(1.56 \%)$, germacrene-D $(1.50 \%)$, B-pinene $(1.25 \%)$, sabinene $(1.13 \%)$ and pulegone ( $1.12 \%)$. The essential oil composition of Mentha pulegium determined in our study showed a profile relatively similar to those published for other geographical regions: piperitone (38.00\%), pipériténone (33.00\%), $\alpha$-terpineol $(4,70 \%)$ and pulegone $(2.30 \%)$, have been reported as a major component of an essential oil of Iran [16], menthone, isomenthone, isomenthol, menthol and pulegone in Uruguay [17], pulegone, pipériténone and isomenthone in Bulgaria [18], pulegone (43.3-87.3\%), menthone (6.7\%), isomenthone $(22.6 \%)$, piperitone (2.13\%) and pipériténone (26.73\%) in Algeria [19], and piperitone (1.3-3.2\%), pulegone (65.9-83.1\%), menthone (8.3
-8.7\%), isomenthone (3.8- 4.0\%), neo-menthol (0.7-1.3\%), pulegol acetate (0.1-1.2\%), $\gamma$-terpinene (0.9-1.2\%) ), ß-caryophyllene (0.1-0.9\%) and $ß$-caryophyllene oxide (0.3-1.9\%) in India [20]. On the other hand, this composition is different from that of the essential oil of Mentha pulegium leaves studied in Tunisia and Morocco, where the main components were respectively menthol (48.56\%) [21] And pulegone (73\%), 33\%) [22]. The essential oil composition of Mentha spicata In the plains of northern India, the carvone content varied between $45.9 \%$ and $77.1 \%$ [23]. The percentage of carvone also varies according to the spearmint oil grown in different countries, eg Egypt (46.4\% -68.55\%) [24,25], Canada (59\% -74\%) ) [26], in Colombia (61.53\%) [27]; Turkey (78.35\% -82.2\%) [2830], China (55.45\% -74.6\% [31], Bangladesh (73.2\%) [32], Algeria (59.4\%) [33] and Morocco (29\%) [34] Lesser amounts of carvone were reported in Iranian Spearmint essential oil (22.4\%). A chemotype rich in linalool $(82,8 \%)$ has also been reported in Turkey [19] in another report on M. spicata essential Iranian oil, $\alpha$-terpinene (19.7\%), piperitone oxide (19.3\%) isomenthone $(10.3 \%)$ and $\beta$-caryophyllene (7.6\%) have been reported as major components.

\section{Conclusion}

The essential oil yield of the plants studied Mentha piperita, Mentha pulegium and Mentha spicata is acceptable. The essential oil of Mentha piperita is rich in Menthone (42.97\%) and Menthol (27.64\%), the most abundant chemical compounds in the essential oil of Mentha pulegium are piperitone (31.27\%) and piperitenone (22.98\%) and for Mentha spicata the presence of carvone (33.14\%) and trans-Carveol (20.06\%). Several factors could be responsible for these variations: the age of the leaves, the nature of the soil and the climate, the part of the plant subjected to extraction and the period of harvest.

\section{References}

1. Stambouli Hassiba, M Babali Brahim, M Kechairi Réda, Bouziane Z (2017) Contribution à l'étude ethnobotanique des plantes médicinales de la région d'Azail (Tlemcen-Algérie).

2. Delaveau P (1975) Plantes agressives et poisons végétaux. Horizons de France, p 240.

3. Léger A (2008) Biodiversité des plantes médicinales Québécoises et dispositifs de protection de la biodiversité et de l'environnement, Université du Québec à Montréal, Canada.

4. Laghouiter OK, Gherib A, Laghouiter H (2015) Etude de l'activité antioxydante des huiles essentielles de certaines menthes cultivées dans la région de Ghardaïa. Revue El Wahat pour les Recherches et les Etudes 8(1): 84-93.

5. Adjou ES, Aoumanou MM (2013) Efficacité des extraits de plantes dans la lutte contre les moisissures toxinogènes isolées de l'arachide en postrécolte au Bénin. Journal of Applied Biosciences 70(1) : 5555-5566.

6. Hmiri S, Rahouti M, Habib Z, Satrani B, Ghanmi M, et al. (2011) Évaluation du potentiel antifongique des huiles essentielles de Mentha pulegium et d'Eucalyptus Camaldulensis dans la lutte biologique contre les champignons responsables de la détérioration des pommes en conservation. Bulletin de la société royale des sciences de liège 80: 1.

7. Boland IJ, Mancini PME, Glussiani CD, Jourraspe JB(1982) Volatile leaf oil of Eucalyptus delegatensis seedling. Phytochemistry 21(10): 24672469. 
8. Chennoufi R, Morizur JP, Richard H, Sandret F (1980) Étude des huiles essentielles d'Eucalyptus globulus du Maroc. (Feuilles de jeunesse et feuilles adultes). Riv Ital EPPOS 62 (7): 353-357.

9. Zrira S (1992) Les huiles essentielles d'Eucalyptus du Maroc. Facteurs influençant la productivité et la qualité de ces essences. Investigation sur les possibilités d'exploitation d'E.camaldulensis pour la production d'huile essentielle d'Eucalyptus à cinéole. Thèse Doctorat ès-Sci. Agron. IA V Hassan II. Rabat Maroc.

10. Hajji F, El Idrissi A, Fkih-Tetouani S, Bellakhdar J (1989) Étude des compositions chimiques de quelques espèces d'Eucalyptus du Maroc. Al Biruniya, Rev Mar Pharm 5 (2): 125-132.

11. Sandret FG (1967) Eucalyptus globulus et E. cineorifolia pour la production d'huiles essentielles au Maroc. Annales de la recherch forestière au Maroc 9, rapport 1965: 259-279.

12. Sokovic MD, J Vukojević, M Molecules (2009) Chemical composition of essential oils of Thymus and Mentha species and their antifungal activities. 14(1): 238-249.

13. Ashok K, S Chandra, P Dutt, B Lal Kaul, A Tava, et al. (1999) Essential oil composition of Mentha x piperita L. from different environments of north India. Flav Fragr J 14(1): 5-8.

14. Behnam S, M Farzaneh, M Ahmadzadeh, AS Tehrani (2006) Composition and antifungal activity of essential oils of Mentha piperita and Lavendula angustifolia on post-harvest phytopathogens. Commun Agric Appl Biol Sci 71(3): 1321-1326.

15. Derwich E, Benziane Z, Taouil R, Senhaji O, Touzani M (2010) Aromatic plants of morocco: GC/MS analysis of the essential oils of leaves of Mentha piperita. Advances in Environmental Biology 4(1): 80-86.

16. Mahboubi M, Haghi G (2008) Antimicrobial activity and chemica composition of Mentha pulegium L. essential oil. J Ethnopharmacol 119(2): 325-327.

17. Agnihotri V, Agarwal S, Dhar P, Thappa R, Kapahi B, et al. (2005) Flavour and Fragrance Journal 20(6): 607-610.

18. Stoyanova A, Georgie V, Kula J, Majda T (2005) J Essential Oil Res 17: 475-477.

19. Beghidja N, Bouslimani F, Benayache S Chalchat (2007) J Khimiya Prirodnykh Soedinenii 4: 394-395.

20. Agnihotri V, Agarwal S, Dhar P, Thappa R, Kapahi B, et al. (2005) Essential oil composition of Mentha pulegium L. growing wild in the north-western Himalayas India. Flavour and Fragrance Journal 20(6): 607-610.

21. Marzouk B, Ben Hadj Fredj M, Chraief I, Mastouri M, Boukef K, Marzouk Z (2008) Chemical composition and antimicrobial activity of essential oils from Tunisian Mentha pulegium L. J Food Agric Environ 6(1): 78- 82.
22. Derwich E, Benziane Z, Boukir A, Benaabidate L (2009) Chem Bull "POLITEHNICA" Univ. (Timisoara) 54(68): 85-88.

23. Bahl JR, Bansal RP, Garg SN, Naqvi AA, Luthra R, et al. (2000) Qualitative evaluation of the essential oils of the prevalent cultivars of commercial mint species Mentha arvensis, M. spicata, M. piperita, M. cardiaca, M. citrata and M. viridis cultivated in indo-gangetic plains. J Med Arom Plant Sci 22(1): 787-797.

24. El-Waheb A, Mohamed A (2009) Evaluation of spearmint (Mentha spicata L.) productivity grown in different locations under Upper Egypt conditions. Res J Agric Biol Sci 5(3): 250-254.

25. Foda MI, El-Sayed MA, Hassan AA, Rasmy NM, El-Moghazy MM (2010) Effect of spearmint essential oil on chemical composition and sensory properties of white cheese. J Am Sci 6: 272-279.

26. Zheljazkov VD, Cantrell CL, Astatkies T (2010) Yield and composition of oil from Japanese cornmint fresh and dry material harvested successively. Agron J 102(6): 1652-1656.

27. Roldán LP, Díaz GJ, Duringer JM (2010) Composition and antibacterial activity of essential oils obtained from plants of the Lamiaceae family against pathogenic and beneficial bacteria. Rev Colomb Cienc Pec 23: 451-461.

28. Telci I, Sahbaz N, Yilmaz G, Tugay ME (2003) Agronomical and chemical characterization of spearmint (Mentha spicata L.) originating in Turkey. Econ Bot 58: 721-728.

29. Hua CX, Wang GR, Lei Y (2011) Evaluation of essential oil composition and DNA diversity of mint resources from China. Afr J Biotechnol 10(74): $16740-16745$

30. Chowdhury JU, Nandi NC, Uddin M, Rahman M (2007) Chemical constituents of essential oils from two types of spearmint (Mentha spicata L. and M. cardiaca L.) introduced in Bangladesh. Bangl J Sci Ind Res 42(1): 79-82.

31. Boukhebti H, Chaker AN, Belhadj H, Sahli F, Ramdhani M, et al. (2011) Chemical composition and antibacterial activity of Mentha pulegium L. and Mentha spicata L. essential oils. Der Pharm Lett 3(4): 267-275.

32.Znini M, Bouklah M, Majidi L, Kharchouf S, Aouniti A, et al. (2011) Chemical composition and inhibitory effect of Mentha spicata essential oil on the corrosion of steel in molar hydrochloric acid. Int J Electrochem Sci 6: 691-704.

33. Hadjiakhoondi A, Aghel N, Zamanizadech Nadgar N, Vatandoost H (2000) Chemical and biological study of Mentha spicata L. essential oil from Iran. DARU J Pharm Sci 8(1): 19-21.

34. Rasooli I, Gachkar L, Yadegarinia D, Bagher MR, Astaneh SDA (2008) Antibacterial and antioxidative characterization of essential oils from Mentha piperita and Mentha spicata grown in Iran. Acta Aliment 37(1): $41-52$
This work is licensed under Creative Commons Attribution 4.0 License

Submission Link:

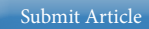

DOI: 10.32474/DDIPIJ.2018.01.000120

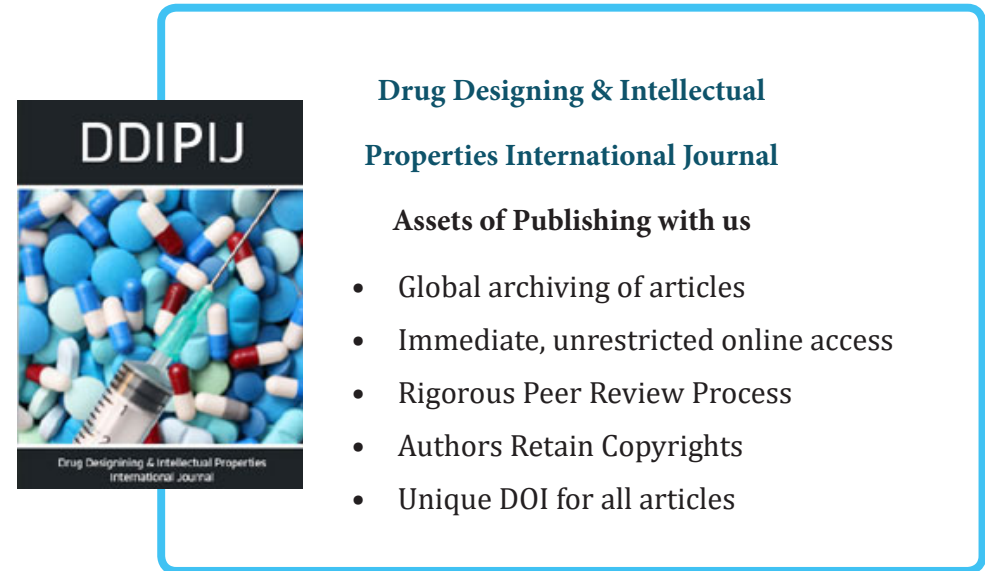

